Man and Nature

L'homme et la nature

\title{
Jonathan Richardson's 'Hymn to God'
}

\section{Carol Gibson-Wood}

Volume 8, 1989

URI : https://id.erudit.org/iderudit/1012599ar

DOI : https://doi.org/10.7202/1012599ar

Aller au sommaire du numéro

Éditeur(s)

Canadian Society for Eighteenth-Century Studies / Société canadienne d'étude du dix-huitième siècle

ISSN

0824-3298 (imprimé)

1927-8810 (numérique)

Découvrir la revue

Citer cet article

Gibson-Wood, C. (1989). Jonathan Richardson's 'Hymn to God'. Man and Nature / L'homme et la nature, 8, 81-90. https://doi.org/10.7202/1012599ar

Copyright (C Canadian Society for Eighteenth-Century Studies / Sociéte canadienne d'étude du dix-huitième siècle, 1989
Ce document est protégé par la loi sur le droit d'auteur. L’utilisation des services d’Érudit (y compris la reproduction) est assujettie à sa politique d'utilisation que vous pouvez consulter en ligne.

https://apropos.erudit.org/fr/usagers/politique-dutilisation/ 


\section{Jonathan Richardson's 'Hymn to God'}

Writing in 1732 to his friend Jonathan Richardson senior, the portrait painter, Alexander Pope referred to his yet unpublished Essay on Man as 'the Essay to which you are so partial.' ${ }^{1}$ Soon after, Richardson reaffirmed his admiration by sending to Pope a poem of praise, "To the Concealed Author of an Essay on Man,' which Pope later published. ${ }^{2}$ It is not surprising that Richardson felt a particular regard for the Essay on Man; not only had he been one of the few people who knew of the Essay's authorship before Pope published it anonymously in 1733 , but he had also himself written a long poem with very similar themes twenty years previously. Richardson's poem is not a literary masterpiece like Pope's Essay on Man. It was written under entirely different, and very personal circumstances, and was not among Richardson's many published writings. ${ }^{3}$ Entitled 'Hymn to God,' it exists only in a seventy-page autograph manuscript which seems hitherto to have attracted no scholarly attention whatsoever. ${ }^{4}$ I believe it is of considerable interest, however, and will attempt to indicate why in what follows.

Richardson wrote out the 'Hymn to God' in January of 1711/12, when he was about forty-five years old; it thus predates all of his published works, the earliest of which was An Essay on the Theory of Painting of 1715. The poem is dedicated by Richardson to his children, and its long preface contains biographical information which both sheds new light on the painter's life and provides a context for the 'Hymn.' In the preface, Richardson apologizes to his children, the oldest of whom was about eighteen at the time, for the fact that he will not be able to leave them a very large inheritance. One of the reasons for this, he says, was his late start in his profession; he lost several precious years by being 'put into a wrong Path at ye first setting out.' This confirms George Vertue's statement that Richardson trained as a scrivener before he apprenticed as a painter. ${ }^{5}$

The second excuse given by Richardson deserves quotation in full:

Another disadvantageous Circumstance with respect to the improvement of my Fortunes has been that my Faculties were usually divided into two several Channells, a great part of the Vigour of my Mind as been diverted from Proffitable Persuits to Enquiries after Religious Truths, Speculative, \& Practical. But 
especially about 7 years ago this Pious, Inquisitive Disposition was accidentally rais'd to a mighty height and being still fed with new matter \& several Incidents unhappily concurring the other Channell was almost dry'd up, whilst this overflow'd its Banks to that degree that it had almost carry'd away my present Fortune, \& Hopes of Future. However, by the Good Providence of God I escap'd, tho not without great Labour, \& detriment, and much Perturbation of Mind. ${ }^{6}$

We know that Richardson suffered some sort of religious crisis early in his career from remarks made by his son, Jonathan junior, in his posthumously published Richardsoniana and Morning Thoughts, the latter being an annotated collection of some of his father's poetry. ${ }^{7}$ We learn therein, for example, that the painter was consulting such eminent divines as Bishops Fleetwood and Tenison during his period of religious doubts. But the 'Hymn to God' provides an early account by Richardson himself that clarifies the extent to which he was totally preoccupied with these issues in about 1703. Furthermore, the Hymn itself makes explicit the religious position at which Richardson eventually arrived.

He dedicated this testimony of faith to his children as a sort of spiritual legacy. Unable to leave them great material wealth, he offers them his 'Hymn' in the hope that it will help to enrich their minds, for, he says, 'Noble \& Justifiable Ideas of God, of Religion and Notions of the State of things, Contentment, \& a certain way of improving everything to our Advantage' constitute 'a sort of Mental Wealth' which is just as important as a glittering fortune. Richardson has no illusions about this 'Hymn' being great poetry; he says that he simply believed his thoughts 'would be more agreable in Verse, tho incorrect, than in Prose.' He wrote the 'Hymn' in short lines of unrhymed verse.

As its title indicates, the poem is basically a hymn of praise and thanksgiving to God. Within this framework, however, Richardson reveals much about both his personal values and the philosophical positions which he had examined, rejected, or accepted. I will briefly outline the contents of the 'Hymn,' and then focus on some of its more interesting themes. It begins with a discussion of the omnipotence and perfect wisdom of God, which includes consideration of man's place within the great chain of being, and the necessary imperfections of man. Richardson then describes what a more perfect world than our own would hypothetically be like. This is followed by descriptions of various parts of God's creation, including celestial bodies and other worlds, the sea, the elements, animals and plants, by which His existence is known. His description of human attributes includes discussion of the roles of self love, passion and reason in determining our 
actions. He next turns to domestic pleasures, notably the state of matrimony, and finally a declaration of his own aims and values in daily life. The two major themes that run through the 'Hymn' are first, that our knowledge of God's perfect wisdom and pre-determined scheme of things should be a source of happiness and security to us; and second, that it is reason which both rules God's eternal scheme, and makes knowledge of Him possible on our part.

In discussing aspects of Richardson's 'Hymn,' I will reverse his order of topics and begin with themes of biographical interest and then end with his philosophical position. Comments on Richardson's character that have survived from the eighteenth century portray him as a pious, earnest, mild-mannered person, who took himself very seriously and was a coffee-house bore. ${ }^{8}$ We also know that he was seemingly deeply affected by his wife's death in middle-age, and that he had a very close relationship with his son Jonathan junior. The 'Hymn to God' confirms the accuracy of this characterization, but provides extended examples of Richardson's attitudes in his own words. Appraising his own character, for example, he writes that he is:

At Peace within, with God \& all the World

And if I have an Enemy am none.

Farr fom Indifferent as to what is said

Concerning me, of Reputation,

And of Applause desirous, but if

Another sees less Merit in me than

I think I have, not angry nor disturb'd

Am I at that suppos'd Mistake, Nor when

Defects are seen in me my Selfe observe.

Honest \& meaning well, Dispos'd to do

To others as I would be dealt with all.

Listning to Natures Dictate when I eat,

Or Drink, or other Nat'ral Wants supply;

Guided by Reason, not by Passion driv'n:

Performing All I do as done for God,

By him observ'd, directed, \& approv'd. (fol. 65)

We can perhaps believe the anecdote that Henry Fielding would 'run a furlong' to avoid Richardson, whom he called 'Dr. Fidget.'

It is clear that Richardson placed a high value on domestic happiness and matrimonial love. His words on these subjects may be of more than biographical interest in so far as they are strongly stated examples of what social historians of this period have identified as emerging attitudes of the middling orders of society. 'Choicest Gift, my other 
Half!' Richardson calls his wife, and proceeds to list her many virtues, painting thereby a picture of the qualities desirable in a wife:

Kind, Chast, Discreet, Grave, Chearfull, Thrifty, True, Handsome, not Vain, Verbose or Turbulent, Clean, Neat, Genteel, but plain, not fond of Mode, And less affecting Singularity.

Humble, Affable, but knowing well Thy Character, \& well sustaining it, As Mother, Mistress, \& my Wife, Not apt To take Offence not giv'n, or design'd Nor long resenting what deserves rebuke. Well bred, because not troublesome, or stiff, Saying, or Doing what may give Offence, But ready to oblidge; not Ignorant Of Ceremonys us'd, nor inexpert At those important Trifles, Counterfeit Too oft, but Currant Coin, which all demand, But none esteem of any real worth.

Not destitute of fit accomplishments Improving Natural Gracefulness, Not Nice, Dainty, Luxorious, but temperate.

With simple cleanly Nourishment best pleas'd.

Not Sauntring, Dull, Inquisitive of what

Concerns thee not, but ever well employ'd, Surrounded with thy Daughters, Happy they If thus instructed Thee they imitate! Business to Thee Diversion is, \& Home, The pleasantest Place, rarely diverted else, And then they chief Companion is thy Dear. Healthy thou art (O maist thou long be so!) Thou knowst is too, not Fancifull: Thy mind Is Even, Calm, Unconscious of Ill, And Ignorant of what is best unknown. With this Condition satisfied \& pleas'd, Intent on House hold Good, Devout enough, Practicing Vertue, \& Believing Right, That is believing as the Church requires, Implicitly, without Examining. Religious therefore as a Woman should Whose Faith should by her Works appear, \& in The Repetition of her Creeds consist. 
For Disquisitions Theological

Are Exercises Masculine, robust,

And Women should no more dispute than Fight. (fols. 57-8)

Richardson's wife was seemingly a passive, if supportive bystander through his own period of religious inquiry.

This list of his wife's admirable qualities is followed by Richardson's description and celebration of the happiness he has found in marriage: 'Nor History, nor Poetry can boast / Of Wedded Love more perfect than is ours' he claims, for example (fol. 60). This in turn is followed by a more abstract discourse on the advantages of 'Sacred Wedlock.' His preoccupation with these themes is also evident elsewhere in the 'Hymn.' One of the most touching sections of the poem is a long passage (fols.52-4) about the unhappy circumstances of losing a beloved spouse. Although Elizabeth Richardson was perfectly healthy in $1711 / 12$, this description seems vividly to foretell her death in middle age in 1726, and Richardson's reactions to that event. Roger Lonsdale has drawn attention to a remarkable series of poems (posthumously published in Morning Thoughts) which Richardson wrote on the subject of his bereavement. ${ }^{10}$ Some of the very themes and metaphors of these, such as the experience of dreaming of a departed spouse, had in fact been developed fifteen years earlier in the 'Hymn to God' where, however, they form part of a hypothetical situation, as opposed to an experienced one. The deep affection and regard which Richardson had for his wife, and his profound fear of losing her which are expressed so clearly in the 'Hymn,' put into perspective the long-lasting grief which her death actually occasioned.

The Hymn's most successful passages as poetry are perhaps some of Richardson's evocative descriptions of parts of God's creation, or of the details of imagined situations. There is quite a poetic outburst about clouds, for example (fol. 24), and a very effective portrayal of a plague (fols.28-32). We know from his published writings that Richardson particularly admired the ability of painters like Raphael to enrich a narrative with appropriate details, and of poets like Milton to create vivid pictures by means of words. In parts of the Hymn, like the plague description, he seems himself to be attempting this sort of evocative representation of a scene or series of scenes which involve human activities and emotions.

Among his wife's virtues, Richardson had praised her for believing implicitly what the Church of England required. Elsewhere in the poem he refers to his own religious beliefs as being on the whole 'Not inconsistent with the publick Faith, / What the Established Church Believes, and Wills/ To be believ'd by all within her reach' (fol. 68). They may 
not have been inconsistent with orthodox dogma, but they are of a marked deistic nature, similar to the ideas expressed in Pope's 'Essay on Man.' In his personal quest for faith, Richardson came out clearly on the side of natural religion, and secure in his belief that 'Whatever is, is right.'

The optimistic fatalism of Richardson's views is evident in the early pages of the 'Hymn to God' and is restated in a number of ways throughout. One of his initial descriptions of God's omnipotence reads:

Governing always, irresistable,

Unchangeable, impossible to Err,

Impossible to Will but as it does,

Such the Perfection of thy Nature is!

A little further on he writes:

In thy vast Mind the Book of Fate is writ

Without beginning, without Date; to us

Invisible; Beyond the present all

Thy wisdom, \& thy Goodness hath conceal'd.

Compare these lines to Pope's more elegant couplet: 'Heav'n from all creatures hides the book of Fate,/All but the page prescribed, their present state' (Essay on Man, I, 77-8). In another formulation, similar to Pope's 'Whatever is, is right,' but typically more verbose, Richardson says, 'All that is done is done by Thee \& is / All things consider'd wisest, noblest, best' (fol. 4).

Like Pope, Richardson also addresses the problem of why, if God is perfect and everything has been preordained by him, we live in an imperfect world. Their answers are similar: what look like evils or shortcomings to our eyes are actually directed to some greater aim within God's infinite plan. So Richardson writes:

'Tis highest Wisdom to oblige a Fool

To Act his part for noble purposes:

By our Irregularitys wise Ends

Impossible to be attain'd without

To Thee yet necessary because Wise,

Thou hast, \& dost, \& ever wilt attain

Whether by us observ'd, or not, \& oft

They are unknown to us, or dimly seen.

And twenty years later Pope writes: 
So Man, who here seems principal alone,

Perhaps acts second to some sphere unknown,

Touches some wheel, or verges to some goal;

'Tis but a part we see, and not a whole. (Essay on Man, I, 57-60)

But whereas much of Pope's argument in the first part of the Essay on Man is directed at criticizing the pride of man in thinking himself the main object of the universe, Richardson's discussion has rather different ends. His serves as a justification of his own contentment with his lot, and as a statement of doctrine for his children. In the preface to the 'Hymn to God' Richardson says that he has not 'gone into the Proof' of the notions expressed in the poem, because he has done so 'elsewhere in my other writings.' Exactly what these 'other writings' were which Richardson had completed before 1711 we do not know; no manuscripts survive of the philosophical proofs of his religious beliefs. However, I think parts of these early speculative writings may survive in Richardson's Two Discourses, his work on connoisseurship which was published in 1719. The first edition of the Two Discourses contains some rather lengthy digressions on theological and philosophical issues; these sections of the book were apparently sharply criticized, and they were omitted or drastically shortened in subsequent editions. ${ }^{11}$ In any case, Richardson's inclusion of this sort of material in his arttheoretical works is now easier to understand, given the background of the 'Hymn to God.'

Another of his beliefs which is clearly stated in the 'Hymn,' and which must originally have been supported by a long-winded argument in his 'other writings,' was that God's existence can be inferred using reason from the natural world, without the need of supernatural revelation or religious institutions. (fols.16-17) He refers, for example, to:

Intellectual Light that views

Through Space imence, \& to Eternity

Backward, \& forward, even to thyselfe,

Inferring Thy Existence from Effects

Notorious, Indisputable, which

By any steps conveys us up to Thee. (fol. 7)

Or again, at the beginning of his descriptions of God's creations, he says:

When I behold Thee as thou art beheld

By reason, or those Rays of Deity,

Thy Works in Heaven, on Earth or in Ourselves ...

I Behold incessantly thy Face, O God. (fol. 20) 
And at the end of his appreciation of the cosmos, he exclaims:

But above all (tho seldom well observ'd)

None more inflames the Mind with Gratitude,

Commands our Praise, \& Adoration more

Than that God hath reveal'd himself to us;

The Light that Lightens every Man hath shewn

Without the help of Preists, or Oracles,

In this, or that by-corner of the World

Appearing, or distinguishing themselves

Not only what wee are to do, but that

Reason Eternally, \& every where,

Infinite Reason over all presides.

The Evidence for this is clear \& strong. (fol. 56)

A more outspoken version of these views occurs in an interesting section of the 'Hymn,' alluded to above, in which Richardson portrays what a more perfect world than our own would be like. He describes the inhabitants of such a world as possessing clearer reasoning powers than our own, such that they can demonstrate many truths, including the existence of God, which we must accept merely as probabilities:

Endued with Reason, clear, \& strong they know

And can demonstrate what to us appears

But probable, or doubtful, tho desir'd ...

These can indeed demonstrate God exists

And what is Justice Goodness Rectitude ...

Nor Revelation needs, all Deists here ...

They know the sacred Will \& as they know

They practice; here no magistrates, no Laws,

No Preists are seen, For on their hearts engraven

Thy Precepts are. (fols.16-17)

Other examples of Richardson's wish to dispense with organized religion, and his particular abhorrence of rituals associated with Roman Catholicism, occur throughout the 'Hymn.'

Parallel passages expressing these same ideas in more elegant and concise form are again to be found in Pope's Essay on Man. Like those with fatalistic overtones, these passages were the ones found most exceptionable by Pope's continental critics, and defended by Warburton. Not surprisingly, however, on the issue of religious rites and priests, the Essay is less outspoken than Richardson's 'Hymn.' 
I do not wish to suggest that Richardson's 'Hymn to God' necessarily served as a direct source of ideas or inspiration to Pope when he was writing his Essay on Man. However, I do think that Richardson's manuscript should be of interest not only to those like myself who are concerned with Jonathan Richardson's life and ideas, but also to Pope scholars. Pope and Richardson were close friends from at least as early as 1725 until Pope's death; as their surviving correspondence indicates, they enjoyed one another's company and frequently got together for purposes of informal conversation. ${ }^{12}$ Much has been made in Pope scholarship of the possible influence of Bolingbroke's philosophical ideas on the content of the Essay on Man. But surely Richardson's significant presence should also be acknowledged. He was an intimate friend who had struggled at a personal level with these cosmic issues, and who, after much reading, consulting and reflection, had emerged from his doubts firmly believing in natural religion and a fatalistic Providence. Everything that we know about Richardson reveals that he was very open about discussing his beliefs with his friends, and very ready to show them examples of his poetry. Pope may well have read Richardson's 'Hymn to God', for he encouraged his friend's aspirations as a writer.$^{13}$ I think that there can be little doubt that Pope and Richardson had often dwelt in conversation on many of the issues raised in the Essay on Man. Jonathan Richardson junior tells us that both he and his father were 'witness to the whole conduct of it [the Essay] in writing; ${ }^{\prime 14}$ it is very unlikely that they were mute witnesses.

\section{CAROL GIBSON-WOOD}

Queen's University

\section{Notes}

1 George Sherburn, The Correspondence of Alexander Pope (Oxford, 1956), vol. III, p. 326.

2 The Works of Alexander Pope (Edinburgh, 1767), vol. II, pp. 173-4.

3 Richardson did, however, cite a few lines of the poem on p.97 of his Two Discourses (London, 1719) without indicating their source. In the 1773 edition of his Works, which were edited by his son, their derivation from a 'Hymn to God' is cited (p.202). That this 'Hymn to God' must have been an unpublished work by Richardson was noted by W.G. Snelgrove in The Work and Theories of Jonathan Richardson (unpublished PhD thesis for the University of London, 1936), p.18. Snelgrove was unaware of the existence of the complete 'Hymn to God' manuscript, however. 
4 British Library Additional MS 10423. I am grateful to the British Library for permission to quote from this manuscript. The preface is signed 'J.R.' and its contents indicate that it was written by a painter. The handwriting matches that of Jonathan Richardson Sr., as found in the annotations he placed on the drawings which were in his collection. Despite the fact that the authorship of the manuscript was correctly identified in a 19th century B.M. catalogue, and is still catalogued under Richardson, it has not been commented upon by any other author that I know of. On Richardson's published poetry, see: Leon Guilhamet, The Sincere Ideal. Studies on Sincerity in Eighteenth-Century English Literature (Montreal and London, 1974), pp. 151-161; and Roger Lonsdale, "Jonathan Richardson's Morning Thoughts," in Augustan Studies. Essays in Honour of Irvin Ehrenpreis, edited by D.L. Patey and T. Keegan (Newark, 1985), pp. 175-194.

5 The Walpole Society, vol. XXII: Vertue III (1933-34), pp. 23 and 67.

6 BL Add.MS 10423, fol. 2. Folio references to this manuscript will hereafter be given following citations in the main text.

7 Richardsoniana: or, Occasional Reflections on the Moral Nature of Man; Suggested by various Authors, ancient and modern, and exemplified from those Authors. with several anecdotes interspersed. By the late Jonathan Richardson, jun. Esq. (London, 1776). Morning Thoughts: Or Poetical Meditations, Moral, Divine and Miscellaneous. Together with several other poems On Various Subjects. By the Late Jonathan Richardson, Esq. (London, 1776). For a full discussion of this scarce volume, see Lonsdale.

8 The principal commentators on Richardson's character, besides his son, are George Vertue (in his notebooks, published by The Walpole Society), Horace Walpole (in his Anecdotes of Painting in England, 1762-80), and Ephraim Hardcastle [William Pyne], in Wine and Walnuts; or, After Dinner Chit-Chat, 2 vols. (London, 1823).

9 Ephraim Hardcastle [Walter Pyne], Wine and Walnuts, vol. I, p. 109.

10 Lonsdale, pp. 189-192.

11 See Carol Gibson-Wood, 'Jonathan Richardson and the Rationalization of Connoisseurship,' Art History, vol. 7, no.1 (1984): 38-56.

12 Sherburn reproduces fifty-one letters from Pope to Richardson; Pat Rogers lists eight additional ones in 'Not in Sherburn,' British Journal for Eighteenth-Century Studies, vol. 8, no.1 (1985), 59-64; and Maynard Mack notes two more in " 'Affectionate Touch': Letters from and to Pope", The Scriblerian, vol. XX, no. 1 (Autumn 1987), 1-7.

13 For example, in a letter of 1732 to Ralph Palmer, Richardson says that, 'I had last year considerable progress upon those four Hymns of Callimachus which Prior had not done. Those Mr Pope oblig'd me to finish.' National Library of Scotland, MS 3420, fol. 163r. Pope also read through the manuscript of Richardson's book Explanatory Notes and Remarks on Milton's Paradise Lost before it was published in 1734. The fullest discussion of Pope's friendship with Richardson is W.K. Wimsatt's, in The Portraits of Alexander Pope (New Haven, 1965), pp. 73-89, 137-222.

14 Richardsoniana, p. 264. 